\title{
LANGUAGE CULTURE and CURRICULUM
}

Executive Editor: Eoghan MacAogáin, Linguistics Institute of Ireland

Review Editor: Pádraig Ó Riagáin, Linguistics Institute of Ireland

Editorial Board:

Richard Benton, Jim Cummins, John Edwards, Alan Hudson-Edwards, Carl James, Jim McCloskey, Gerhard Neuner, P. Sture Ureland, T. J. M. van Els.

This journal provides a forum for the discussion of the many factors, social, cultural, cognitive, and organisational which are relevant to the formulation and implementation of language curricula. Second languages, minority and heritage languages are a special concern. First-language and foreign language studies are also welcomed when they have implications for multiculturalism.

The journal will discuss the varieties of multilingual education and language maintenance programmes to be found around the world in order to clarify the distinctive patterns of needs served by second languages. It hopes to develop a perspective on these issues that will draw extensively on mainstream research in education, sociology, psychology, politics, public administration and cultural studies. It will also draw on research on language which often fails to have its full impact in the classroom because of inadequate models of programme implementation, including models of the cultural context in which language learning takes place.

Language Culture and Curriculum will provide practical guidelines for the design and implementation of language curricula with cultural objectives, taking into account organisational factors in the school and the community.

\section{Details of recent issues:}

\section{Volume 1 No. 3. Special Canada-Ireland Issue}

Volume 2 No. 1

- National Versus Regional Models of Language Variation; Paul Rusch

- The School as a Bargaining Point in Language Politics; Selma K Sonntag

- Learning to Talk About People; Towards an FL Syllabus for Adult Learners; Peter Broeder

- Staff Development for Teachers of Language Minority Students; Liliana Minaya-Rowe

- The Relationship Between Culturally Relevant Materials and Listening Comprehension of Canadian Native Indian Children; William McEachern and Frances Luther

Volume 3 (1990) 3 issues Individuals $\mathbf{E 1 6 . 0 0}$ (US\$33.00)
Libraries/Institutions $\mathrm{f} 47.00$ (US\$97.00)

Students $\mathrm{f} 8.00$ (US $\$ 17.00$ )

\section{Payment may be made by}

ACCESS/MASTERCARD/EUROCARD/AMERICAN EXPRESS/DINER'S CARD

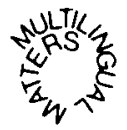

MULTILINGUAL MATTERS LTD Bank House, 8a Hill Road, Clevedon Avon, England, BS21 7HH

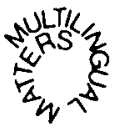




\section{Oceanic Linguistics}

IS UNIQUE among linguistic journals in presenting a mix of datarich and theoretical articles.

EMPHASIZES IN-DEPTH ARTICLES on specific indigenous languages and the reconstruction of parent languages.

FACILITATES COMMUNICATION and research in linguistics across national boundaries and over a geographically broad area covering Oceania and parts of Southeast Asia.

OFFERS A BOOK-REVIEW SECTION that aims to keep readers aware of the latest publications in the field of linguistics.

SPANS DISCIPLINES, appealing to readers interested in Asia-Pacific prehistory, physical anthropology, archaeology, reconstructive linguistics, and relationships among Asia-Pacific peoples.

Volume 30, Number 2 (Winter 1990) Special issue on Languages of Western Austronesia James T. Collins, guest editor

Volume 30, Number 1 (Summer 1990)

Lexical Transfer from Marshallese to Mokilese

Locative Accent in Samoan

The Tones of Kairi

USA/Canada: Individuals US\$1S, Institutions US\$20

All other areas: Individuals US\$16, Institutions US\$23 Airmail postage: Add US\$12/year

UNIVERSITY OF HAWAII PRESS

Journals Department

2840 Kolowalu Street, Honolulu HI 96822 U.S.A. 


\section{SOCIAL PROBLEMS}

\section{SPECIAL ISSUES}

LANGUAGE, INTERACTION AND SOCIAL PROBLEMS, Volume 35:4 (October 1988)

THEMATIC ISSUE ON THE SOCIOLOGY OF SCIENCE AND TECHNOLOGY, Volume 35:3 (June 1988)

SPECIAL THEORY ISSUE, Volume 33:6 (December, 1986) FEMINIST ISSUES AND WOMEN'S PROBLEMS, Volume 32:4 (April 1985)

THEMATIC ISSUE ON THE FAMILY, Volume $31: 3$ (February, 1984)

THEMATIC ISSUE ON JUSTICE, Volume 30:5 (June, 1983)

THEMATIC ISSUE: TECHNIQUE AND THE CONDUCT OF LIFE, Volume 30:3 (February, 1983)

THEMATIC ISSUE ON HEALTH AND ILLNESS, Volume 30:1 (October, 1982)

ETHICAL PROBLEMS OF FIELDWORK, edited by Joan Cassell and Murray L. Wax, Volume 27:3 (February, 1980)

$\$ 9.00$ per issue, $20 \%$ off to members.

PUBLISHED BY THE UNIVERSITY OF CALIFORNIA PRESS FOR THE SOCIETY FOR THE STUDY OF SOCIAL PROBLEMS

For subscription/membership information, contact:

University of California Press Journals 2120 Berkeley Way

Berkeley, California 94720 


\section{sociolinguistica}

Internationales Jahrbuch für Europäische Soziolinguistik

International Yearbook of European Sociolinguistics

Annuaire Internationale de la Sociolinguistique Européenne

Herausgegeben von / edited by / édité par

Ulrich ammon, Klaus J. Mattheier, Peter H. Nelde

Vol. 3 (1989):

Dialect and School in the European Countries

1989. XIII + 221 p. Paper DM 76.- / US-\$ 46.-. ISBN 3-484-60330-5

Contents: Foreword. - P. van DE CRAEN, Belgium. - U. AMmon, Bundesrepublik Deutschland. - J. N. Jørgensen, Denmark. - K. Spangenberg, Deutsche Demokratische Republik. - B. Loman / P. Rintal., Finnland. - J. Cheshire, Great Britain. - J. Harris, Ireland. - A. M. Hagen, The Netherlands. - G. Wiggen, Norway. - H. Gadler, Österreich. - M. E. Ricardo Marques, Portugal: Le Retornados. - M. Ciolac / M. Chioreanu, Roumaine. P. Sieber / H. Sitta, Schweiz. - M. Siguan, Spain: Regional Language and Dialect. - L.G. Anderson, Sweden. - D. Kalogjera, Serbo-Croatian Dialects and School in Yugoslavia. - Reviews. - Bibliography 1987.

Vol. 4 (1990):

Minorities and Language Contact

1990. XII + 253 p. Paper DM 86.- / US-\$ 50.-. ISBN 3-484-60346-1

Contents: Preface. - R. RindLer SchJerve, Les Minorités et la Linguistique de Contact. Méthodes de Recherche. - H. GoEBL, Methodische Defizite im Bereich der Rätoromanistik. Kritische Bemerkungen zum Stand der soziolinguistischen Diskussion rund um das Dolomitenladinische. - S. Gustavsson, Socialism and Nationalism. Trends and Tendencies in the Language, Nationaliy and Minority Policy of the Socialist Countries in PostWar Europe. - J. TREFFERS / J. van DEN HAuwE, French Borrowings in Brussels Dutch. P. VAN DE CRAEN, Allochthonous minorities and contact Linguistics. Towards a Language Learning Paradigm based on Social Linguistic Principles. - G. Lüd, Les migrants comme minorité linguistique en Europe. - A. M. HAGEN / KEES DE BOT, Structural loss and levelling in minority languages and dialects. - N. Denison / J. TRAGUT, Language Death and Language Maintenance. - M. HARTIG, Minderheiten und Mehrsprachigkeit. - L. AUbuRGER, Linguistic Minority Relations. - Reviews. - Bibliography 1988.

Vol. 5 (1991): The Languages in the European Organizations (EC, COMECON)

Vol. 6 (1992): The Rise of National Languages in Eastern Europe

Vol. 7 (1993): Multilingual Concepts in European Schools

Vol. 8 (1994): English only? in Europe

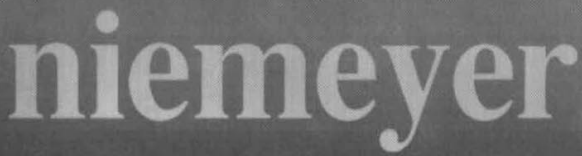

Max Niemeyer Verlag · P.O. Box 2140 - D-7400 Tübingen 


\section{STUDIES IN \\ LANGUAGE}

MANAGING EDITOR

John W.M. Verhaar

Divine Word Institute

Madang, P.N.G.

INTERNATIONAL JOURNAL

SPONSORED BY THE FOUNDATION

"FOUNDATIONS OF LANGUAGE"

REVIEW EDITOR

Werner Abraham University of Groningen

The Netherlands

\section{SCOPE AND OBJECTIVES}

The journal deals with subjects basic to contemporary linguistics and philosophy, in the sense that it focuses on the foundations of language. Specifically it covers:

(1) traditional areas of linguistics, descriptive as well as formal and typological, i.e. phonology, morphology, syntax, semantics, and pragmatics

(2) linguistic theories derived from various methods of language analysis

(3) contributions to the study of the foundations of language made within such fields as sociology, anthropology, psychology, language acquisition, mathematics, communication theory, artificial intelligence, theory of argumentation, law, ethics, traditional areas of the philosophy of language (analytical philosophy, phenomenology, hermeneutics)

(4) logical systems with strong compatibility with natural languages

(5) methodology of linguistics, etc.

\section{SUBSCRIPTION}

Subscription rates to STUDIES IN LANGUAGE (2 issues, 525 pages) are as follows:

Hfl. 275,- (US\$ 137.50) plus postage (Hfl. 30,-/US\$ 15.00) for Libraries and Institutions payable after receipt of an invoice.

A reduced rate of $\mathrm{Hfl}$. 80,- (US\$ 40.00 ) (postage and handling included) is offered to individual subscribers, provided that their prepaid order is placed directly with the publisher and that copies will not be made available to institutions.

For a prospectus or sample copy please write to Jacqueline Buijs at the Amsterdam address

\section{JOHN BENJAMINS PUBLISHING COMPANY}

P.O.Box 52519 - Amsteldijk $44 \cdot 1007$ HA AMSTERDAM - Tel. (020) $738156 \cdot$ Fax (020) 739773 821 Bethlehem Pike · PHILADELPHIA, Pa. 19118 - USA · Tel. (215) 836-1200 · Fax (215) 836-1204 


\section{LANGUAGE IN SOCIETY \\ NOTES FOR CONTRIBUTORS}

Contributions are welcomed from all countries. They should be written in English. All articles, as well as books for review and listing, should be sent to Professor Dell Hymes, Editor, Department of Anthropology, University of Virginia, Charlottesville, VA 22906-9024, U.S.A.

Typescripts. The original typescript plus one copy should be submitted. Authors should hold a copy for correction of proofs. Contributions should be clearly typed, double-spaced on $81 / 2 \times 11$ " or $\mathrm{A}_{4}$ paper. Figures should be ready for photographic reproduction: any labels and details should be clear and large enough to remain legible after a $50 \%$ reduction. The article title page should include the title, author's name and affiliation (in that order), along with an abstract of the article. An abstract must be less than 150 words. Areas of study should be listed at the end of the abstract.

Tities should be worded so that the first part may be used as a running head (with a maximum length of 50 characters, including spaces). The title should be typed on a separate sheet with the author's name and address to which proofs should be sent.

Citations and forms of emphasis. Normally the Latin alphabet is to be used. Cited forms should be underlined to represent italicization in print. Translation meanings should be placed within single quotation marks.

References are to be made in the text (not in the endnotes) by giving in parentheses the name of the author, year of publication, and, where relevant, the page(s) referred to: (Whitney 1867:45- 53). If the author's name is part of the text, the following form should be used: "Whitney (1867:48) maintained that. ..." When a work written by two or more authors is referred to, all names should be given in the first citation: (Weinreich, Labov, \& Herzog 1968). In subsequent citations, only the first name should be given, followed by "et al.": (Weinreich et al. 1968). Separate works referred to in the same parentheses should be listed in alphabetical order; those by the same author should be separated by commas, and those by different authors by semi-colons: (Firth 1935, 1957a; Whitney 1867). Initials should be used (before the author's name) only when it is necessary to distinguish between two or more authors with the same surname referred to in the same article.

All works referred to must be listed at the end of the article, double-spaced and in alphabetical order.
Examples of references (note the use of punctuation marks within references):

Firth, J. R. (1957a). Ethnographic analysis and language with reference to Malinowski's views. In R. W. Firth (ed.), Man and culture: An evaluation of the work of Bronislaw Malinowski. London: Routledge \& Kegan Paul. 93-118.

(1957b). A synopsis of linguistic theory: 1930-55. Studies in linguistic analysis (Special volume of the Philological Society). Oxford. 1-33.

Sapir, E. (1929). The status of linguistics as a science. Language 5, 207-14. Reprinted in D. G. Mandelbaum (ed.), Selected writings of Edward Sapir. Berkeley and Los Angeles: University of California Press, 1939. 160-66.

Book reviews and notices. With the exception of the title page, book reviews and notices should be submitted in the same form as articles. The title page should take the following form:

HENK HAVERKATE, Speech acts, speakers, and hearers: Reference and referential strategies in Spanish (Pragmatics \& Beyond V:4). Amsterdam and Philadelphia: John Benjamins, 1984. Pp. $x i+142$.

On the last page, following the entire review text, endnotes, and references, the review author's name and address should be given as follows:

Reviewed by BEATRIZ R. LAVANDERA Instituto de Lingüistica Universidad de Buenos Aires Buenos Aires, Argentina

There is no need to submit an abstract with a book review or notice.

Proofs. First proof will be sent to the lead author (or a nominee), who will be expected to correct and return them to the Editor, by airmail where appropriate, within three days of receipt.

Offprints. 25 offprints of the article will be provided free of charge to the lead author. Additional offprints may be purchased if ordered at proof stage.

Submission of an article is taken to imply that it has not previously been published or is not being considered for publication elsewhere. If an author is publishing a related article elsewhere, this fact should be stated.

Copyright. Contributors of accepted articles will be asked to assign their copyrights, on certain conditions, to Cambridge University Press, to help protect their material, particularly in the U.S.A. 


\section{Language in Society}

Volume 19 Number 2 June 1990

ARTICLES

J. Holmes: Apologies in New Zealand English

R. K. HerberT: Sex-based differences in compliment behavior 201

S. Fisher \& S. B. Groce: Accounting practices in medical interviews

\section{REVIEWS}

Language contact and creolization

G. G. GLBERT (ed.): Pidgin and creole languages: Essays in memory of John E. Reinecke (Romaine)

P. MÜhlhüusler: Pidgin and creole linguistics; and S. Romaine: Pidgin and creole languages (Hancock)

J. R. Rickford: Dimensions of a creole continuum: History, texts, and linguistic analysis of a Guyanese Creole (Baker)

S. G. Thomason \& T. Kaufman: Language contact, creolization, and genetic linguistics; I. LEHISTE: Lectures on language contact; and R. WARDhaugh: Languages in competition, dominance, diversity, and decline (van Coestem)

P. Trudgill: Dialects in contact (Rickford)

Writing, literacy, literature

H. J. GrafF: The legacies of literacy: Continuities and contradictions in Western culture and society (Peters)

C. A. BOWERs: The cultural dimension of educational computing (Kleifgen)

M. Nystrand: The structure of written communication: Studies in reciprocity between writers and readers (Sperling)

B. A. RAFoth \& D. L. RuBIN (eds.): The social construction of written communication (Hardman)

E. Schauber \& E. Spolsky: The bounds of interpretation: Linguistic theory and literary text (Traugott)

N. Fabb, D. Attridge, A. Durant, \& C. MacCabe (eds.): The linguistics of writing: Arguments between language and literature (Hymes)

(c) 1990 Cambridge University Press 